\title{
HEREDITARY STUDIES ON CONGENITAL ATRESIA OF THE EAR
}

\author{
By \\ H. HAYASAKI \\ From the Department of Otorhinolaryngology, School of Medicine, Keio University \\ (Director: Prof. T. Nishihata)
}

The systematic hereditary studies of congenital atresia of the ears of 98 families among $14 \%$ patients were observed. These patients consisted of the outpatients of the Depertment of Otorhinolaryngology, Keio University Hospital, patients examined in Shizuoka-Prefecture, students in Primary and Junior High Schools in Tokyo and Deaf-mute Schools in Japan.

The results were as follows:

1) The possibility of heredity could be considered. The reasons are as below mentioned.

(a) The familiar appearances were found among 98 families.

(b) The morbidity was $2.02 \%$ among probands' fathers and $0.61 \%$ among their aunts. These morbidities were higher compared with $0.0016 \%$, the mean of the morbidities of the general population.

(c) The same disease was found in twin brothers (monozygotic twin supplied by Dr. Fujita)

2) It was pointed out by many authors that the sex ratios in hereditary malformations and diseases: were higher in the male than in the female. The ratio observed by the author was $78.49 \%$ in the male and $21.51 \%$ in the female patients. Affected-side ratios were $30.63 \%$ on the left, $63.96 \%$ on the right and $5.41 \%$ on both sides. These ratios were almost similar to those reported by American, European and other Japanese authors.

3) Several associated malformations and congenital diseases are often found in probands, their sibships and other relatives when one congenital malformation is investigated. The observation of these associations were also very important in view of the embryology and heredity. In my studies, the associated ratio was $18.18 \%$ in probands and $29.90 \%$ in their families. The kinds of associations were Atresia auris congenita, congenital paralysis of facial nerves, congenital lameless, congenital scoliosis, microphthalmus congenita, polydactylia, several kinds of psycosis, congenital deaf-mutism, etc.

4) The familiar appearances were not frequent enough to investigate the families of the 98 probands by means of statistical and hiometry examination. But by observing their pedigrees directly. the auther obtained the results as follows:

(a) In most pedigrees, the charactor appeared in the father's or mother's side only.

(b) There were pedigrees that the charactor was handed down from one of the parents to their children.

(c) The intermarriage ratio, as observed by the author, was $8.08 \pm 2.72 \%$, which had no significant difference compared with $4.69 \pm 0.33 \%$, the ratio of the general population reported by Dr. Kawakami, and $7.1 \%$ reported by Dr. Tachikawa.

(d) The morbidity of their sibships was very low, in spite of the fact that the morbidity percentage would be higher in their sibships if this disease had a very low percentage and followed. the recessive hereditary system.

(e) The penetrance of this disease was $1.02 \pm 10.09 \%$ among 98 pedigrees.

From the above stated results, the author concludes that Atresia auris congenita follows the dominant hereditary system with very low penetrance. 


\section{先天性外耳道閉鎖症の遺伝学的研究}

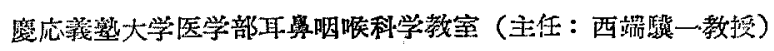

是 崎 引晃

目次

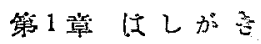

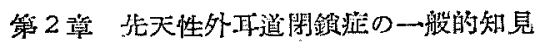

第1篗定喓

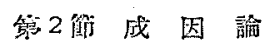

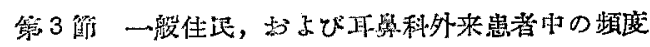

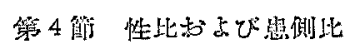

第 5 䐄 含 说 旅

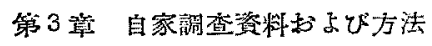

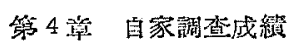

管 1 䇛 家系洭例

第2 節 家族性出垷拉例

筫 3 㑑血族結婚究

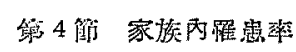

管 5 篗 表 現 彎

第 5 望 䋓括ならびに考察

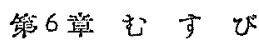

\section{第1章はしがき}

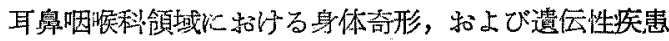





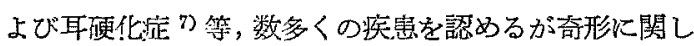

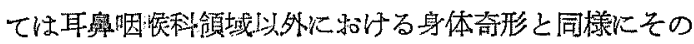
遗伝性について等に家系調查を行うと意外にも家族性 出現の少いものがある・このためか今日です，な特一般に は奇形の成因に関しては遺伝的因子よりも環境的因子が 多く考えられているよらに思われる・本疾䖩むこの例 るれず，従来之の成因としては，乙の大部分が㻴摬的因

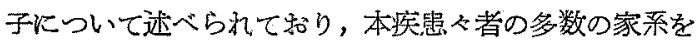
調查し，その遗伝についての系統的方究を行つた報告は 末だ内外の交献中に見出す事ができず，単に同一家系内 に本疾患を認め遗伝説を腤示した数例に接するのみであ

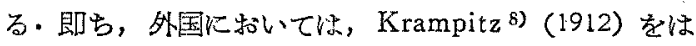
じめ 12 例の報告と，我国に括いては，堌田 ${ }^{9)}$ (1956)， 浅抹 10) (1957) の夫ネ1例の報告のみで放る・私は，今 日迄遗伝的因子の䦭与については不明とされている本疾 患につき観察し，144 例の本矣㭧々者中 98 家系を調查，

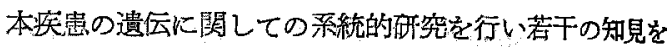
得たので势賢の御批判る们ぐ次第である。

第 2 章 先天性外耳道閉鎖症の一般的知見

符 1 節 定 掌

先天性外耳道閉鎖泟とは，その文字の示す如人，先天 性に外耳道の閉鎖されているものを総称するがこれ法 通常 2 種類に大別される・その一つは，外耳道が軟部組 織により閉鎖されている膜性閉鎖で，この場合は末成育 の外耳道が梁部に旨状を呈して存在する・後者は，外耳 递が骨により閉鑜されている骨性閒鑜で，骨性外耳道が 久如しており，鼓脱は稀江痕跡程度に存在する他は，殆 ど全てに諗められず，耳小骨は全く存在しない例よりは ぶ正常の形態を有する 例に至るまで理くの段階がある が，桘骨亡砧骨が㽷着を示している事が最も多い. 膜生 閉鎖は骨性閉鎖に較べて非常に稀である・我トの教室で 点力改善手術を行つた本疾患々者，22 例，23 側につい ては前者は1例にすぎず，これとは別に本疾患々者の耳 部の断篔撮影を行つた 12 例に和いても全例に骨性外耳

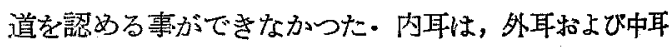
とは発生泉基を異にするためか，私が直接検查した本咨 㷛た者 43 例では，その機能はほな正常であつた・

第 2 節 成 因論


に発育阻止のために生ずるばかりではなく，急性ならび に慢性の刺㦸機転による過剩発育も関与寸ると説さ， Joel 12) はVirchow と同様汇発育阻止および炎症病变 を原因とし，その誘因として遺伝梅畵視している。 Moos u. Steinbrügge ${ }^{13)}$ は，本疾患の多くは，蹗器に 拉ける腔洞の大部分が，骨翼常発育により閉鎖又は充実 する事を本店患の主因として，脳神経異常，体質異常， 梅毒又は，アルュール中毒等による肧胞発逳障碍，羊膜 噔盖，あるいは臍带纆絡等をあげ，特に Alexander u.

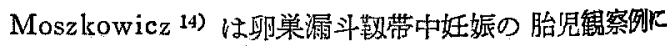

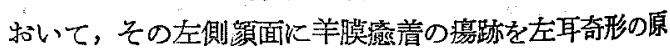
因とし，外部加らの機峨的発育阻止作用により惹起され

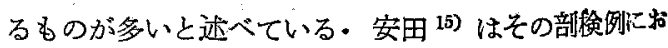
いて第一㙰弓に和ける異常発育であり，認められた各部 


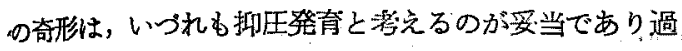

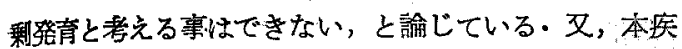

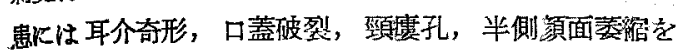
伴ら事が多い理由から，Moos, Steinbrügge, および Wreden 16) 等は第一咽破裂の改造期に 発生するものと 考えられる，と述べている・又，前述の対く，家族性出 現を認め，それを報告した Krampitz を初め数名の学: 者は遭伝も因子の一つに考えられる可能性がある，と遗 公説を暗示している・この他，Sundal 1) は，放射能， X 線子因于になりらる，と述へ，Gillman ${ }^{18)}$ (1948)， Hamburgh, Wadding ton ${ }^{19)}$ (1952). 呿よび林 ${ }^{20)}$ (1952), 村上21)(1955) は妊赈中の実駼動物に Trypanblue を 静注する事化より各理身体奇形の発現を見ている・ Gillman によれば，60〜80\%に奇形を認め，この中 5.9 \%に耳部の奇形を見た，と報告している・このように本 疾患の発生譏転こついては種その説があり末だ定説がな w.

第3 節 一般住民および耳舆利外来患者中の㥧度 西石疾患の遗伝につき系統的酚を行らに当つては，


するかを明らがする等が必要でる・艺して，その家

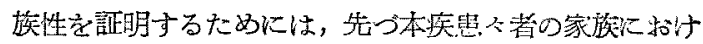

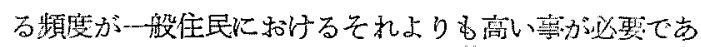
る・しかし，本疾患の一般住民に指ける碩度に四して は，内外交献中には，これを全く見出す称ができない。

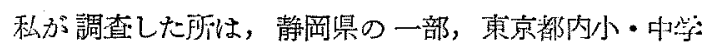

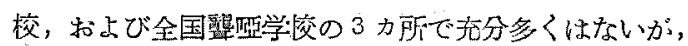
Table 1. の如くで，本疾虫がいかに稺な疾留であるか， といら凡その推定はつくと思われる・

各所耳鼻科を訪れた患者中，本疾患の頻烈は Table 2. の対くである・

このよ5に Table 1, 2 に糸子如く，本疾蚛は耳鼻斗

Table 1. Incidence of congenital atresia of the ear (by the author)

\begin{tabular}{l|c|c|c}
\hline & No. of affected & Total number & Frequency (\%) \\
\hline Shizuoka Prefecture & 13 & $1,034,827$ & 0.0012 \\
\hline $\begin{array}{l}\text { Primary \& Junior } \\
\text { High Schools in Tokyo }\end{array}$ & 7 & 307,024 & 0.0020 \\
$\begin{array}{l}\text { Deaf-mute Schools } \\
\text { in Japan }\end{array}$ & 33 & 15,025 & 0.2196 \\
\hline
\end{tabular}

Table 2. Incidence of congenital atresia of the ear (reported by the author and others)

\begin{tabular}{|c|c|c|c|}
\hline Author & No. of affected & Total number & Frequency $(\%)$ \\
\hline Jacobson 22) (1883) & 2 & 4.607 & 0.04 \\
\hline Brückner 2$)(1884)$ & 42 & 43,730 & 0.04 \\
\hline Bezold 24) (1904) & 11 & 20,468 & 0.05 \\
\hline Wagenhäusen ${ }^{25}$ ) & 2 & 307 & 0.65 \\
\hline $\begin{array}{l}\text { Toyoda, Komachi }(1940) \\
\text { (19) }\end{array}$ & 11 & 17,374 & 0.06 \\
\hline Hayasaki (1959) & 91 & 53,208 & 0.17 \\
\hline
\end{tabular}

領域における他の疾患に較へて非常に稀な疾患であり本 疾患の家系の調查にあたつては，多くの困難を伴つた． 第 4 節 性比および患側比

性染色体に關係を有しない遗伝性医患においても，先 天性股閣節脱旧のよ 5 K高い性比を示するのがあるが， 本疾患の従来の知見，牤よび私の調查した結果を総括す ると, Table 3. に示す如くである・

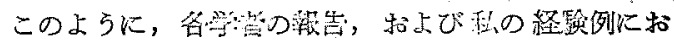

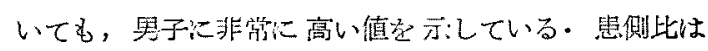
Table 4.K亦したが，この比計算するに当つて，瑟

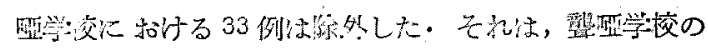

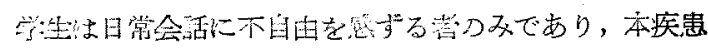

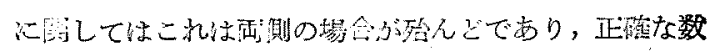

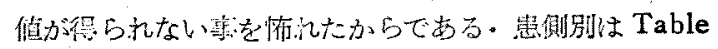


Table 3. Sex ratios (reported by Meurman, Japanese authors and Hayasaki)

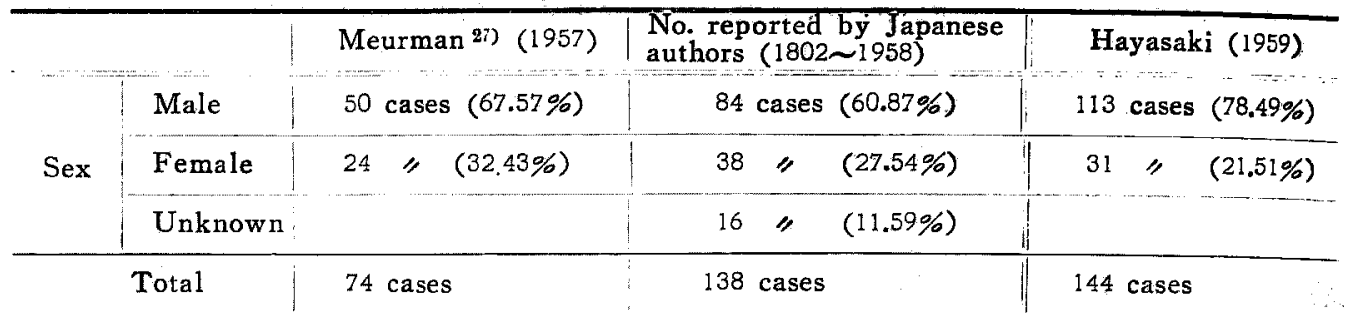

Table 4. Affected side-ratios (reported by Ombrédanne, Japanese authors and Hayasaki)

\begin{tabular}{|c|c|c|c|c|c|c|c|c|c|c|}
\hline & \multirow{3}{*}{$\begin{array}{l}\text { Left side } \\
\text { Right side }\end{array}$} & \multicolumn{3}{|c|}{ Ombrédanne ${ }^{28)}$ (1952) } & \multicolumn{3}{|c|}{$\begin{array}{l}\text { No. reported by Japanese } \\
\text { authors }(1802 \sim 1958) \\
\end{array}$} & \multicolumn{3}{|c|}{ Hayasaki (1959) } \\
\hline \multirow{4}{*}{ Affected Side } & & \multicolumn{3}{|c|}{21 cases $(26.58 \%)$} & \multicolumn{3}{|c|}{30 cases $(20.27 \%)$} & \multicolumn{3}{|c|}{34 cases $(30,63 \%)$} \\
\hline & & 37 & " & $(46.84 \%)$ & 66 & $"$ & $(44.59 \%)$ & 71 & 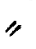 & $(63.96 \%)$ \\
\hline & Both sides & 21 & $"$ & $(26.58 \%)$ & 21 & $"$ & $(17.57 \%)$ & 6 & $"$ & $(5.41 \%)$ \\
\hline & Unknown & & & & 2.1 & $"$ & $(17.57 \%)$ & & & $\therefore \ldots$ \\
\hline \multicolumn{2}{|c|}{ Total } & \multicolumn{3}{|c|}{79 cases } & \multicolumn{3}{|c|}{148 cases } & \multicolumn{3}{|c|}{111 cases } \\
\hline
\end{tabular}

4.に見られる如く、いずれの報告において子右側に高 い值を示している。

このように，本疾患は男子に，そして右側に多く現れ ている事が分る・多くの遗伝的異常の頻度が男子に，上 り商いといら事実は，他の遗伝的異常についても多くの 学者が報告する所であり，私の調查課程において対照の 選び方に差があつたとは思放れないここれは発生の際， 特定の遗伝子に誘発される反応が哭子の背景の下で行わ れる時，女子の場合之違つた経路をたどる結果であ万 ら，という登生上よりの説明と，遗伝による説明として は，特殊な形の多遗伝子説を利用して説明がなされてい るようである・

第 5 節 合 储 淀

一般に，奇形の調查を行らと，発端者およびその傢族 に，他の轜ふの奇形を見出す事があり，これらを調查す る事恃発生学的にも遺伝学的にも重要なる意味がある。 队外の交献中にこれらの記載のあつたものを述べると， Moos, Steinbrügge 和よび Wreden は耳附属症，口

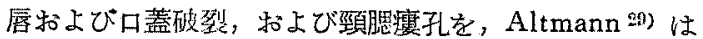
枿骨発育障棏, Sack:(0) は顥蓋骨の奇形, Alexander (1)

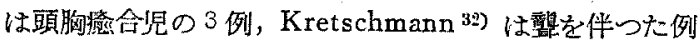
と，1 賌人の同側に先天性顔面神経麻瘦を伴えるものに

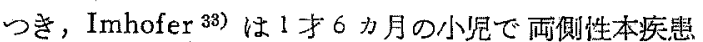

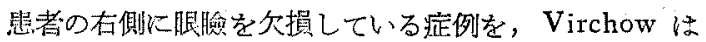

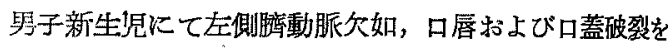
伴つた例を，Schwendt ${ }^{3+1}$ ) は腮溝のう腫の 3 例を， Alexander, Benesi ${ }^{33}$ ) 恃右側の本疾患々者炕右側口蓋 帆の不全麻㿉，右下顎の発育不全例と，同じく右側の本 疾患々者江軟口蓋欠損，右顔面神経，および右外旋神経 麻痹を合併していた例を報告している・我国に竌いて は，岩田 ${ }^{36)}$ が 34 才男子の 本疾患汇 分裂口蓋垂の合侀

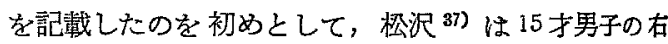
側の本疾患に同側角膜のデルモイドを，藤森36)は1才 男子の両側のものに軟口蓋破裂を，城所 ${ }^{39}$ は22 才男子 左側のものに分裂口蓋垂を，富家 ${ }^{40)}$ は新生児男子の耐 側のものに両側の來唇と狼咽を，大山41) は 5 力月男子 の右側のものに同側顔面横裂を，久慈 42) は2 卵珄双生 卵の第 2 胃男子（第 1 児も男子）の右側のむのに先天性 眼球欠損症，鬼唇，お゙よび奥梁欠損を，河辺 ${ }^{43)}$ (4女子 新生児の左側のるのに大口症，および先天性眼球突出 を，河瀬 44)は2 才男子の右側のものに眼臉下垂，斜 頸，拉よび右側角膜輸部のデルモイドを，後藤 45) 性左 側本疾患の 7 力月男子の父に种唇を，大藤 46 恃本疾患

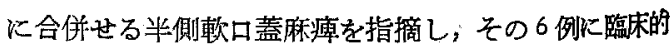
観察を行つている：私が調查を行つた 98 例における発 端者，物よびその家族における合併症，拈よび变質微作 を宗とめて Table 5. に表示する。

これによると，先天珄外耳道開鎖症，先天性跛行，先 
Table 5. Associated malformations and hereditary diseases. (observed by Hayasaki)

\begin{tabular}{|c|c|c|c|c|c|c|c|c|c|}
\hline $\begin{array}{l}\text { Associated malformation } \\
\text { and hereditary disease }\end{array}$ & Sib & Parents & Sibship & $\begin{array}{l}\text { Grd. tather } \\
\text { Grd. mother }\end{array}$ & $\begin{array}{l}\text { Uncle } \\
\text { Aunt }\end{array}$ & Cousin & $\begin{array}{l}\text { Nephew } \\
\text { Niece }\end{array}$ & Others & Total \\
\hline Atresia auris congenita & & 2 & & & 1 & & & & 3 \\
\hline Congenital lameness & & & & & 1 & 4 & 1 & 2 & 8 \\
\hline Congenital scoliosis & 1 & & & & & & & & 1 \\
\hline Congenital microphthalmus & 1 & & & & & & & & 1 \\
\hline Polydactylia & & & & & & 1 & & & i \\
\hline Cogenital nystagmus & 1 & & & & & & & & 1 \\
\hline Congenital speech disorder & 2 & & 1 & & & 1 & & & 4 \\
\hline Congenital hear $t$ disease & 1 & & & & & & & & 1 \\
\hline Deaf-mutismus & 3 & 1 & 1 & & 2 & & & & 7 \\
\hline Congenital blind & & & & & & 1 & & & 1 \\
\hline Mental deficiency & 8 & & & 1 & 4 & & & & 13 \\
\hline Schizophrenia & & & & & 4 & 2 & & 2 & 6 \\
\hline Psychosis Epilepsy & & & 1 & & 1 & & & & 4 \\
\hline M.D.I. & & & 1 & & & & & & 1 \\
\hline Hysteria & & & & 5 & & & & & 5 \\
\hline Total & 17 & 3 & 4 & 6 & 13 & 9 & 1 & 4 & 57 \\
\hline
\end{tabular}

天性側繁，先天性小眼球症，多指症，各種精神症患，先

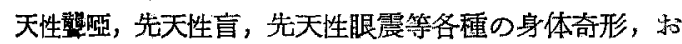
よび遗伝性疾患等表に示す如くである・これら合併症は 発端者においては $18.18 \%$ ，家族の者には29.90\%に見ら れる・なお，同側の耳介奇形，拈よび同側顔面萎縮は発 端者には程度の差はあつても殆ど全てに合併しているの で特別表示せず，又，合併率にる加算はしなかつた・

\section{第3 章 自家調查資料および方法}

調査方針としては，勿論多数の患者について家族調査 を行らべきであるが，前述の如く本疾患は非常に頻度が 低く，又，表現率も低いので家系調查には困難を伴つ た・私の調查の対沼は，我くの臨床を訪れた本疾患々者， 静岡県下の巡回揨療に際して遭遇した本疾患々者，東京


本疾患々者，合計 144 例中 98 例の家系で，直接，患者 家族佰接して調查したものと，アンケートにより調查 しなお，不審な点のある場合は家庭訪問によつてその 点を明らか次した・調查の範用は発端者の同胞，父母， 祖父母，叔伯父母，拉よび従兄弟端妹としたが，地理的

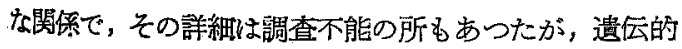
要因について考察を行らのに支障のあつたるのは，これ を全部除外した・このようにして集めた家系より，いか にこれらの成績を遗层学的に分析するか，という事であ るが，現在迄の全文献よりの資料を比較教察す心゙き事梳
勿論是非とも必要な事ではあるが，現在迄の内外の交献 を通読するも M. Schwarz ${ }^{47}$ ), Kahler ${ }^{48)}$ (Fig. 7,8), 牧よび Gaus ${ }^{49)}$ の報告に本疾患々者の 家系を見るのみ であり，その他には全く本疾患な者の家系図の記輔はな く，遺伝学的者察が試みられた報告は見られなかつた。 㺨は本疾患々者の98家系観察し，家族性出現を見た 万家系 (Fig. 1，2，4）も併せて観察する機会を得たの で，本疾患々者の多数例による，遺伝についての采統的 何究が現在迄なされていない本疾患について，遗伝学的 考察を行ら事は意義ある事と考夫，㦑えて報告する次第 である・

\section{第 4 章 自家調查成樍}

第1節 家系症 例

前述の方法により調查を行つた家系総数は98家采で， 部查人員は発端省，交母，祖父母，父采扣よび母系の权 伯父母 733 名，同じく従兄弟姉妹 1050 名の総計 2503 名 であり，一家系の平均調查人員は約 25 名であつた・こ の98家系打，次節にて述べる3家系の家族性出現例の 化はすべて単発例であつた。

\section{第 2 節 家族性出現症例}

私の家系調查を行つた 98 家柔中，家族性に出現を見 た症例は，Fig. 1，2，4の3家系である・図示するに先

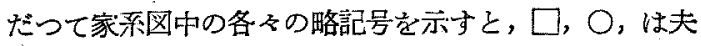
夫健康な男子，女子、罗，罗，溃遺性疾患，あるいは 
Fig. 1. (Pedigree Nc. 26)



Fig. 2. (Pedigree No, 33)

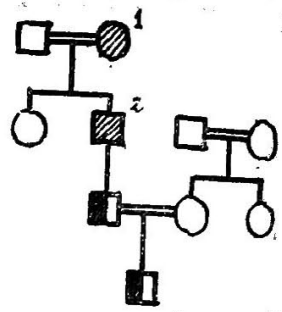

1. Congenital lameness.

2. Mental deficiency.

(3) Congenital lameness.

Fig. 3. Father and his son of Pec. No. 33 above showed.

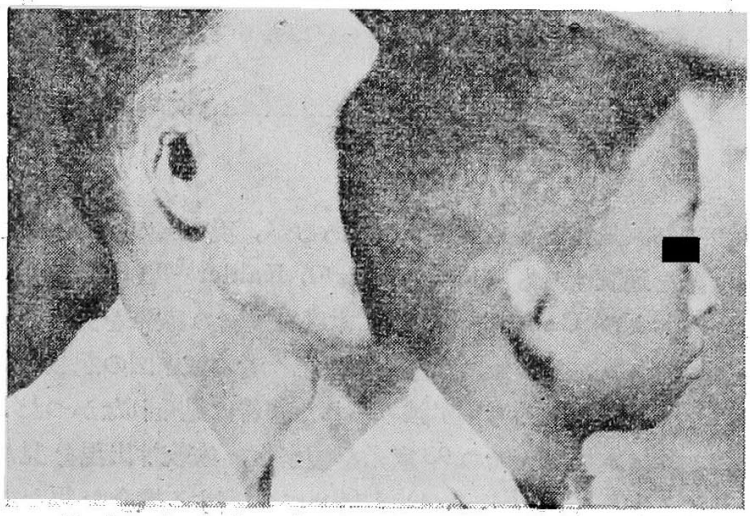

Father had the plestic operation of the ear lobe and the operation to prove the hearing

Fig. 5. Faiher and his son of Ped. Nc. 77 above showed

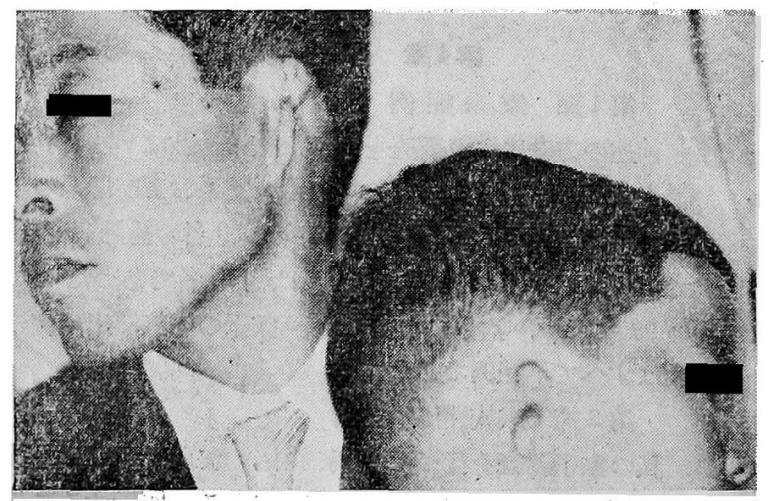

光天性奇形を有する男子，女子・回，，は本疾患々 花肞，女子で，黒色にて示すのは夫々患側である.

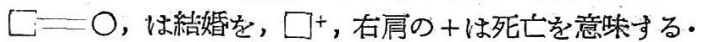

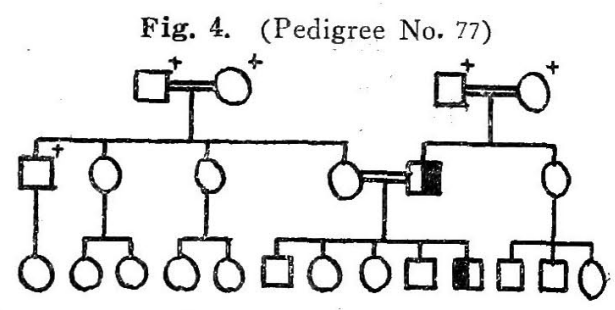

以上示した如く Fig. 1 は血族結婚はあるが采 側に出現して扣り；又, Fig. 2,4 は血族結婚むな く，親から子へ直接形質が伝わつている。

第 3 節 血族結婚率

ある形質の遺伝学的考察を行らに際しては，刘照 内に和ける血族結婚率も大なる意義を有する事惆 知の事である・私の調查観察した98家系につい は，全例に血族結婚の有無について詳しく調查を行 つたが，98家禾中，家系番号 26，50，70，76，84, 89,96の計 7 家系に血族結婚を認めた。これらは粉 て両漞の血族結媘であり，叔父姪結婚の1例を除い

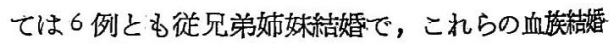
率は一ここの計算にあたつては，眦活)の方法

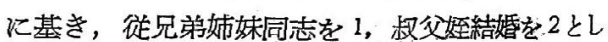
た・— $8.08 \pm 2.72 \%$ であり，川上の東京市内一般 住民の血族結婚率 $4.69 \pm 0.33 \%$ ，立川，桑原 ${ }^{51}$ の $7.1 \%$ とは有意の差を諗めず，本疾患々者家采中の 血族結婚率は一般住民のそれに比して高いとは云兑 ない.

第 4 節 家族内䍜患率

Weinberg の方法の原理に基き；発端者を除外 して, 発端者を中心とし; 男子同胞, 女子同胞， 父，母，叔伯父，特よひ叔伯行分けて，各々の䍜 
费率を計算した結果は，父は 2.02\%で叔伯母は $0.61 \%$ であり，他は0\%であつた・この成績は，この他の単純

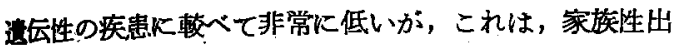
現例のみ期味を持つ事なく，各家族を調查した結果で あり，実際に本疾患は家族性に出現する事は予想に反し て甚だ少いるのである・しかし，この数値は，一般住民 の頻度の正均 $0.0016 \%$ に較べ本疾患子者の家族内にお いて遥か炻高い㕍患率を示し，本疾患の遺伝性は否定で きないすのと思われる。

\section{第5節 表 現 率}

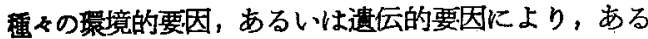
遇层子を持つるのでも，その全員にその遗伝子に対空す 硎質が現れるとは限らないここ上うな種々の条件 の下で，夫くの形質が現れる率を表現率と云う・そ己 て，その遗伝的疾患の種類によつて，表現率にも美のあ る事恃勿論である・この遺伝子の表現率を量で 表わす と，Stưrn 692)に上れば，優性遗伝型式をとるものでは， 第1の方法として，優性遺云子で持主全員に現れるな ら，表現率は100\%である・持主の半数にだけ效果が現 れる るのは，表現率は50\%である・ある特定形質の 表現率を求めるには效果の現われた遺伝子の持主の数 も，划果の現われなかつた持主の数る知る必要がある。 そのためめには，表現不完全な優性形質の患者を子供に持 つている親の中で，両親ともこの形質を持たない場合 と，少くとも片親は患者である場合との数を勘定する. この方法に従らと，私の調查例に批いては，患者を出乙 た家系は 98家系で，この中夫掃の片方が患者であつた のは2組であるので，本疾患が優性遗伝型式をとると仮 定すると，表現率は $1.02 \pm 10.09 \%$ である・第 2 の方法
は片親がーテロの家族を全部集め患児と正常罢を夫た合 計して比を求め，理論比 $1: 1$ を比較する方法であるが， この方法は更に多数の家族にて検討せねばならないと思 われる。

\section{第5章 総括ならびに考察}

内外の交献によると，Czörsz ${ }^{63)}$ は不規則性劣性遺伝 之推測し，Windle (4)（1891）は，発端者之父系の従姉 妹们本疾患を見，Krampitz（1912）は，母と娘の同側 汇，同程度の本疾患を，Torrigiani ${ }^{55)}$ (1927) は，姉妹 2 人に, Ernst-Hanhart ${ }^{66)}$ (1949) は，不完全優性遺伝 と推測， Farbe Hansen 57) (1954) は，姑姝2人に， Frenzel ${ }^{58)}$ は，父が片側，息子火耐側の 本疾患を， Eckert-Mobius ${ }^{\text {(9) }}$ は，母の而側，息子の片側, Bracht (0)) は，父の片側，息子の両側，又，Gaus は，優性遺 伝と推測している。この他，M. Schwarz (1953)，拉よ び Kahler は，夫ふ1例つっ，数代亘つて本疾患を 見た例を，夫ょ家系図と共に報告している（Fig. 6，7）。 又，我国に和いては，增田（1956）は，同胞に2人の本 疾患を，浅井 (1957) は，伯母に本疾患を見た例を報告 している・M. Schwarz と Kahler により報告された 家系図は，下に示す如くであるＦig. 1，2 和まび4に

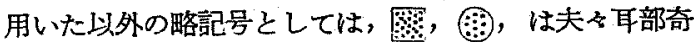
形はあるが，本㗨患の有無が不明である男子，女子を表 わしている。

以上の如く，内外諸学者の症例報告および，家系図よ り見て，又，私の調查成績をもとつして，遗伝学上いか なる解粕を下゙すべか？これらの成績をもつて，本疾 患の成因関与する遺层的因子を否定する竓はでさな いそその根拠は，多数例とは云えないが，家族性に本疾

Fig. 6. Pedigree of Atresia auris congenita (reported by Schwarz)

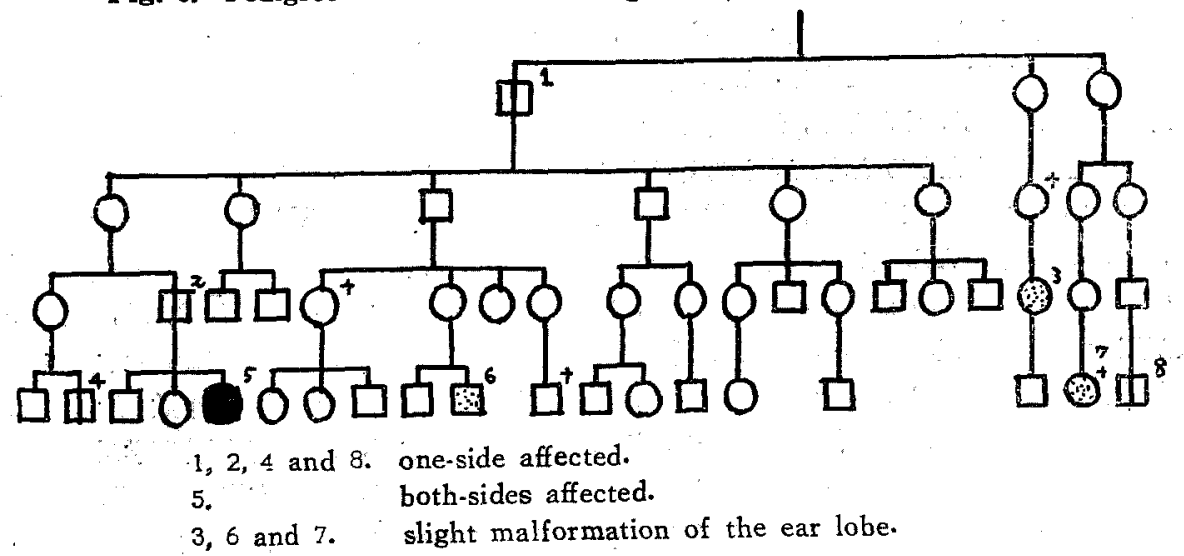


Fig. 7. Pedigree of Atresia auris congenita (reported by Kahler)

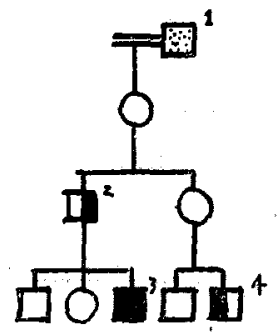

1. Male affected side unknown

2. Male left-side

3. Male both-sides

4. Male right-side

患が出現していると云う事奉と，Table 1. に示す加く， 一般住民中の頻度の平均 $0.0016 \%$ と比較しても，更に， Table 2. に見万如く，耳粤利外来患者中の本疾患の頻 度の平均 $0.16 \%$ と較べて見ても，98家系に特行本疾

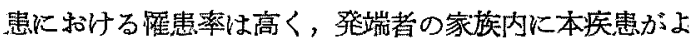
り頻発している事”，又，一卵性双生照の両者（共に男子）

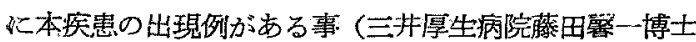
の提供による）等からも，遗伝的因子の関与を無視する 事はできないと思われる・しかし，本疾患の表現率は $1.02 \pm 10.09 \%$ であり，単純遗层性疾患之比較すれぱ甚 だ低いこれる左右行る因子としては，第2 章第2 節で すでに述べた如く，種たの環境因子があげられる・環境 的因子にも，胎児の発育途上飞和いて，子宮内で受ける 種ヶの内環境がある・特に Alexander, Moszkowicz の説に関しては，私も興味ある経験例 (Pedigree No. 30）を持つている・すなわち，目親が双角子宮を持ち (東京都内，某婦人科医の診断によると，右が正常で， 左が小さい)第2子迄 (ともに男子) は，右側子宮にて 正常妊娠，および正常分娩の経過をとつた・発端者であ る第3子（男子）は，左側にて妊娠，生下時体重 640 好 の末熱児であつたが，装いにも一命を取り止めた・そ の後，3回左側にて妊娠したが，発端者の事毛あり，

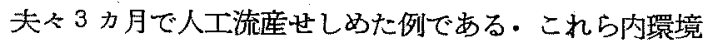
の他に，外㻴境に上る因子，才なわら，母体を介てて胎 児になんらかの影響を与えらると考党られる事第 2 章，第1節に和いて嗵べた所であるが，この種のものに 朗しても，Sundal の説になんらかの関係がありそうな 自験例 61) (Pedigree No. 29) 加ある・この症例は, 19 才の少女が広島で爆心地より $820 \mathrm{~m}$ の地点にて被爆, 明らかな急性放射能症に罹患し，彼女を含生 5 名を除い た他怯全部放射能症で死亡，萃い彼女はこの難を危か れ，4 年後に結婚，被爆後 8 年目に第 1 子（男子）を出 连, その後 2 回の妊娠は, 共に 3 力月にて自然流座, 被
爆後 11 年目に発端者（男子）の出生を見た例である・勿 論この1例だけで，又，之の時の放射能を受けた条件か

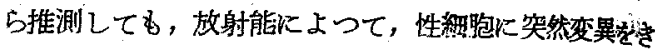
たしたといら可能性は少く，勿論このよ5に断定するも のではないが，又，一方，全くその可能性がないと断 定する事㤌できないと思われる・第 2 に遗伝的背景であ るが，主遗伝子の他に，非常に多数の遗伝子が形筫表現 に站して效果を代柱している事は，遗伝子の相互作用が 大変桡であるといら概念から容易に推測され得る事て ある・ 文，主遗质于の遗伝的背景は個人により異るか ら，一定坐位の主遗伝子を等しくする人達です形質表現 の仕方に善のある事が多いと想像される・なお，私の拥 查例に和いては，母親が妊娠中にら゙ィールス性疾患烟 熹した例はなく，又，狩定の楽品を長期間使用した例る なく，外傷を受けた例る諗めなかつた。ざ，以上私の 調查した成績，および交献上からも本疾患の成因に関し ては，広い意味での環境的无子の他に，遣伝的因子も否 定できないという結論に到達したが，それで性本疾患の 主遺伝子は俱性か㸓性か，といら点が残されている・本 矤患の如く表現率の非常に低い、奇形におい:ては，特優 性少性の決定は極めて困難であるが，恐らくは表現率の 非常に低い不完全優性と考えるのが妥当であるよら反思 われる・この理由としては，家族性出現が少く正確放 計学的，ならびに生物测定学的考察を加える事はでさか からたが，家系図の直接観察によると，1）父系立たは 尉柔の 1 側のみに本疾患が出現する例が多いといら事 年. 2) 家系図で漞から子へ直接，形質の伝つている例 がある事・.3）血族結媘率は 8.08土2.72\%であり，一般 住民中の 血族綕媘率としての川上の $4.69 \pm 0.33 \%$ ，格 び立川の $7.1 \%$ と比較して有意の差を諰めない事 4) 血族結婚率が高く，表現率の非常に低い劣性遗后性疾患 であれば，一般に，発端者の同胞䍜患率が高い，と云わ れているが，私の調查例に括いては，血族結婚率子低

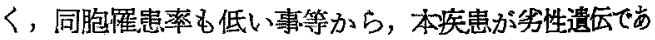
るとは考えにくいという理由によるものである。

\section{第6章むすび}

先天性外耳道閒鎖症の遗伝に関しての系統的研究は現 在迄，症例数の多少を問わず，及，国内国外を問わす行

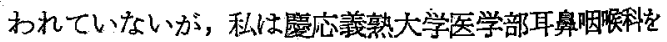
訪れた本疾患々者, 静岡県下数ヶ所の巡回誩潦, 東京都 内小・中学校，末よび全国部沓学校の本疾患々者，合計 144 例中 98 例につさ家族調查を行い，本疾患の遺厷に 閴する系統的研究を行つて次の結果を得た。 
1. 本疾患の成因に閏与しているむの〉1つとして， 息层的因子が考完られる：この根起として，家族性の出 現定例を楞めたという事実，一般住民中の頻度の平均

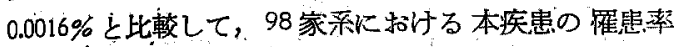
は，父が $2.04 \%$ ，叔伯母では $0.61 \%$ と，発端者の家族 内同疾患がより頻度している事，文，一畞性双生児の 耐方に本疾患の出現を見た事等からも推定されらる事で ある.

2. 他の多くの遺伝的疾患，および先天性奇形は男子 K，上り頙度が高いという事は，多くの学者の指摘する 所であるが，本疾患について，私が調査した結果では， 男子 $78.49 \%$ ，女子 $21.51 \%$ ，患側別は左側 $30.63 \%$ ，右 側 63.93\%，两側は $5.41 \%$ で夫々男子，右側が高い值を 示している・本疾患に関するこれらの数值は, 内外の辩 告の平均值とほ心゙同じ值である。

3. 先天性奇形の調査に際しては，発端者およびその 家族炕，他の種々の先天性奇形にも遭遇与る事があり， 偶然とは考えられない事がある・これらについて調查す る事怯，発生学的にも遗伝学的にも重要な意味があると 思われるが，私の調查では，先天性奇形および遗伝性疾 患の合併率恬，発端者では $18.13 \%$ ，発端者の家族にお いては 29.90\%であり，それらの疾患には先天性外耳道 閉鋇症，先天性跛行，先天性側彎，先天性小眼球症，多 指症，各種精神疾患，㼛咞，先天性眼震等，各種の身体 奇形，占よび遺伝性疾患等が認められた。

4. 遗伝型式については，家族性出貺が少く，正確な 推計学的，ならびに生物学的考察を加える事はできなか つたが，家系図の直接観察によると，父系または母系の 1側の炕本疾患の現れる例が多いという事，親から子 へ直接，形質の伝つている例がある事，私の調べた 98 家称に拈ける血族梽婚は $8.08 \pm 2.72 \%$ であり，川上の 4:69中0.33\%，立川の $7.1 \%$ の夫た一般住民中の血族洁 婚率と比し有意の差がない事，血族結婚率が高く，表現 率の低、劣性遗伝であれば，同胞により高い、羅患率を示 寸傾向があるにも拘らず，本疾患においては，血族結蛅 率㹥一般住民中のれと較べて有意の差がなく，同胞に 本垁患を!例百見なからた事.

以上の事より先天性外耳道開鎖症は，1.02 $10.09 \%$ といら表現率の非常に低い不完全優性遗伝に従うもので あららと推論した。

\section{至考文 献}

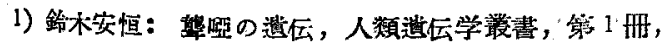

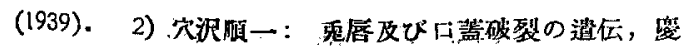

医学，21 (7)；711 770，(1941). 3) 小秋八州男：



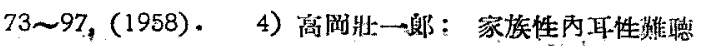
の迷伝学的研究, 日巩暴, 62.(1)；1 16, (1959). 5)



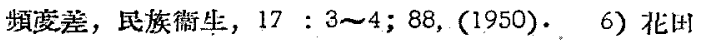

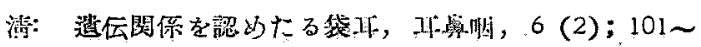

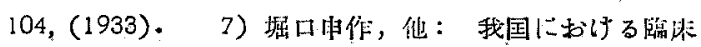

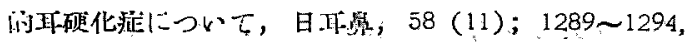
(1955). 8) Pau' Krampitz: Über einiege seltenere Formen von Missbildungen des Gehörorgans. Zschr, Ohr. hk. 65；44 54，(1912). 9) 堆时周 :

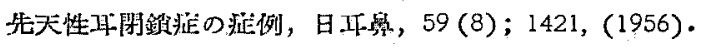


成形手行，耳鼻臨，50 (8);776 780，(1957)。11) Virchow: Über Missbildungen am Ohr v. in Bereiche des ersten Kiemenbogens. Virchow's Arch. 30; 221, (1864). 12) Joel: Über Atresia auris congenita. Zschr. Ohr. hk. 18; 278, (1887). 13) Moos u. Steinbrügge: Zschr. Ohr. hk. 10: 15, (1881). 14) G. Alexander u. L. Moszkowicz: Über eine seltene Missbildung der Ohrmuschel. Arch. Ohr.Nas.-Kehlk. hk. 50: 97 101，(1900). 15) 安

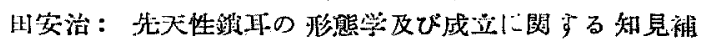

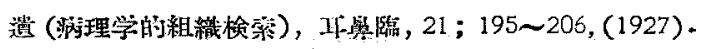
16) Wreden: Beschriebung u. Kritik einer angeborene Missbild des Ohres. Arch. Augenhk. 3 (2): 56. 17) Sundal 5i): cit. par Falbe-Hansen (1954). 18) Gillman: cited by Altmann 29) (1949). 19) Hamburgh \& Waddington: Malformation in Mouse Embryos induced by Trypan Blue. Nature. 169:27 28, (1952). 20) 林一郎, 他：眙生環境

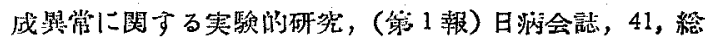
会号；110 112, (1952). 21）柯上比広, 他：界常

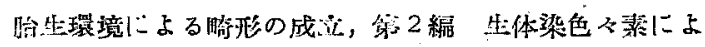

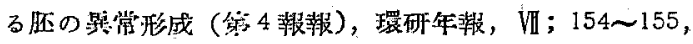
(1955). 22) L. Jacobson: Bericht über die vom 1. Nov. 1877 bis zum I April 1881 untersuchten u. behanderten Kranken. Arch. Ohr..Nas.-Kehlk. hk. 19:28 54, (1883). 23) K. Brückner: Beiträge zur Statistik der Ohrenkrankheiten. Arch. Ohr.Nas.-Kehlk. hk. 20 : 81 103, (1884). 24) Bezold: Hörvermögen bei doppelseitigen angeborener At- 
resie des Gehorrorgans. Zschr. Ohr. hk. 48: 107, (1904). 25) Wagenhausen: 豊田, 小町 26), (1940). 26）豊田，小町：先天性外耳道閉顉症整形例，耳鼻臨， 35(12); 943 948, (1940). 27) Y. Meurman: Congenital Microtia \& Meatal Atresia. A.M.A. Arch. Otolaryng. 66 (4): 443 463, (1957). 28) Ombrédanne, M.M.: 33 operations d' aplasie d' oreille avec imperforation du conduit auditif. Ann. otolaryng 68: 5 45, (1951). 29) F. Altmann: Problem of so-called congenital Atresia of the ear. A.M.A. Arch. Otolaryng. 50: 759 788, (1947). 30) Sack: Ein Fall von Atresie des Gehörorganes durch Missbildung des Schädels u. Facialisatrophie kompliziert. Mscr. Ohr. hk. 47, (1913). 31) G. Alexander: Zur Kenntnis der Missbildung des Gehörorganes besonders des Labyrinthes. Zschr. Ohr. hk. 46. (1904). 32) F. Kretschmann: Kongenitale Facialislähmung mit angeborener Taubheit u. Missbildung des äusseren Ohres. Arch. Ohr.-Nas.-Kehlk. hk. 73, (1907). 33) Imhofer: Beiderseitige angeborene Gehörgangs-atresie u. abgeborenes Lolobom der Augenlider. Passow's Beitrage 4, (1911). 34) A. Schwendt: Über congenitale Missbildungen des Gehörorgans in Verbindung mit brachiogenen Cysten u. Fisteln. Arch. Ohr.-Nas.-Kehlk. hk. 32: 37〜52, (1891). 35) G. Alexander $u$. o. Benesi: Zur Kenntnis der Entwicklung u. Anatomie der kongenitalen Atresie des menschlichen Ohres. Mschr. Ohr. hk. 55: 195 230, (1921). 36) 岩田一：先天性外聴道開塞英耳翼畸北

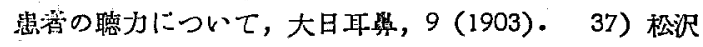

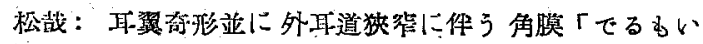

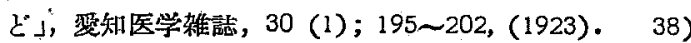


人科学会雑誌，12 (6)；1324，(1929). 39) 城所梧五 郎：小耳件元る先天性外聴道閉鎖の 1 例, 大日耳善,

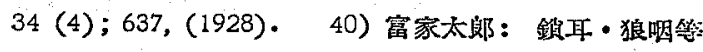
を合併せる畸形完の 1 例，近戴㷌人科学会雑誌，13(2); 428 435, (1930). 41) 大山栄㫌：先天性外耳畸形

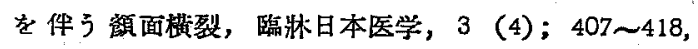

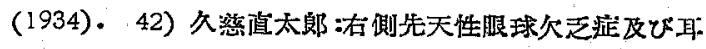
翼夺班，医界展望，209 号; 27, (1939).

43) 河辺目

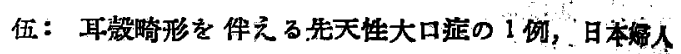
科学会雑誌, 34 (10)；1104～1107，(1937)：４4）河

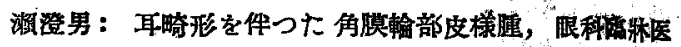
報, 51 (7)；662，(1957). 45）後藤修二，他：先天

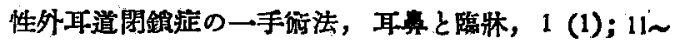

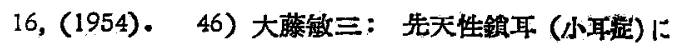

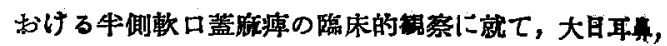
35 (2); 81 90, (1929). 47) M. Schivarz: citiert nach Albrecht (1940). Handbuch der Erbbiologie des Menschen. 4(1): 46. 48) Kahler, 49) Gaus: citiert nach H. Schwarz (1940). Handbuch der Erkrankheiten 6:87 $\sim 91.50)$ 川上理一: 便生学 6 造伝病学. 51) 江川，桑原：小称入州男 3), (1958). 52) Curt Sturn: Principles of Human Genetics. (1949). 53) Czörsz: "cited by Falbe Hansen 5) (1954). 54) Windle, B.C.A.: Teratological evidence as to the heredity of acquired conditions. cited by Journal of the Linnean Sociaty. Londion 23 : 448 502, (1891). 55) Torrigiani, C.A.: citiêrt nach Zentralblatt X]394 Atresia congenita omolaterale del condotto uditivo osseo in due sorelle. Scritti biol., raccolti da Leizi. Castaldi. s. (1927). 56) Ernst-Hànhart: Nachweis einer einfach-dominanten, unkomplizier ten sowie einer unregelmassigdominanten mit Atresia auris, Palataschisis u. anderen Deformationen verfundenen Anlage zur Ohrmuschelkrümmung. Arch. Klaus-Stiftg. Vererbungsforsch usw. 24: 374 398, (1949). 57) Farbe Hansen: Atresia of the external auditory meatus. Acta Oto-laryng. Suppl. 116:76 82, (1954). 58) Frenzel, 59) Eckert-Möfius, 60) Brach: citiert nach H. Schwarz (1940). Handbuch der Erkrankheiten

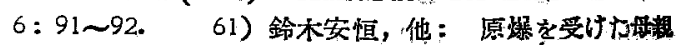


723 725, (1958).

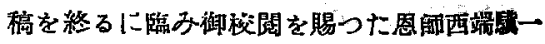

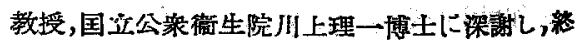

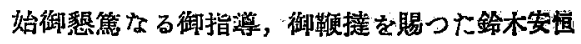

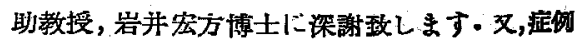

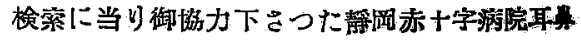
咽啹科医長滈岡壯一郎博士に感謝政します。

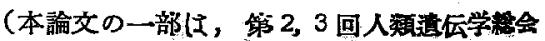
において発諘した)。

（原稿到着二昭和 34.5.4 日) 